\title{
Synthesis and Characterization of Oligomers Composed of Alternating 2,5-Bis(ethynylenedimethylsilylene)thienylene and Arylene Units
}

\author{
Young-Woo Kwak, ${ }^{*}$ Kyung-Koo Lee, Seung-Hun Cha, Sang-Koo Lee, In-Sook Lee, \\ Yong-Tae Park, Jaekeun Lee, Soo-Dong Yoh, and Woo-Sik Kim* \\ Deparment of Chemistn, Kimngpook National Lniversity. Daegu 702-701, Korea

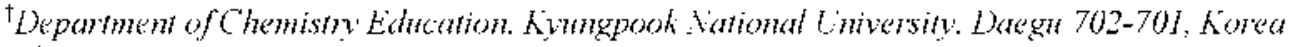

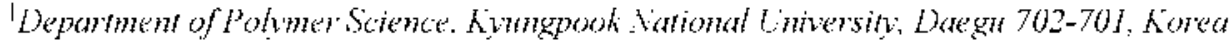 \\ Received Jomany 3,2003
}

\begin{abstract}
The reactions of 2,5-bis(ethyny ldimethy lsily l)thiophene (1) with aromatic dihalides (1,4-dibromoten/enc, 4,4dibromobipheny 1, 9.10-dibromoanthracene. 2.5-dihromepy ridine, 2,5-dibromothiophene, and 2.6-diiodo-4nitroaniline) were earried out in the presence of a $\left[\left(\mathrm{PPh}_{3}\right)_{2} \mathrm{PdCl} \mathrm{l}_{2}\right]-\mathrm{Cul}$ cataly st in relluxing triethy lamine to give poly \{[2,5-bis(ethyny lenedimethy lsilylene)thieny lene] (ary lene)? (2-7) with molecular weights of 2200-7400. The oligomers reveal characteristic absopption in the UV/visible region. The thermal behavior of 2-7 was txamined by themogravimetre analy sis in an argon atmosphere.
\end{abstract}

Key Words : Aromatic dihalides, Dehydrohalogenation, 2,5-Bis(ethynyldimethylsily $]$ )thiophene, Poly \{ 2,5 bis(ethyny lenedimethylsily lene)thienv lenej(arylene);, Thermogravimetric analysis

\section{Introduction}

Organosilicon polymers in which silicon atoms are linked by organic groups with conjugated $\pi$-clcctron sysicms lave been studied intensively over the last decade. ${ }^{+}$Such polymers could be widely used as functional materials ${ }^{2}$ in the field of electronics and material science. Some organosilicon poly mers containing sily lene and dictly ny leneary lene unit might be readily prepared by using the palladium(II)catalyzed coupling reaction of aromatic dilalides with acely lenic reagents reported by Sonogashira. ${ }^{3}$ Cassar. ${ }^{1}$ Dicck and Heck. Harens. ${ }^{5}$ and Trumbo et ol.

Here we describe the preparation and thennal belavior of a series of oligomers composed of a regular alternating arrangement of 2.5-bis(chlyy nenedimelhy lsily lene)thieny.ene unit and arylene unit as the $\pi$-clectron system in the polymer backbone. This type of polymers with an organosilicon moicly and a $\pi$-clectron sysicm has reccived much attention with regard to their heat-resistant properties ${ }^{8.9}$ The oligomers 2-7 are oblained from 2.5-bis(chlyny ldimethylsilyl)thiophenc (1) and (helero)aromatic dilabides $\mathrm{AAr}=$ (helero)aromatic group. $\mathrm{X}=\mathrm{Br}$ or II in the presence of a

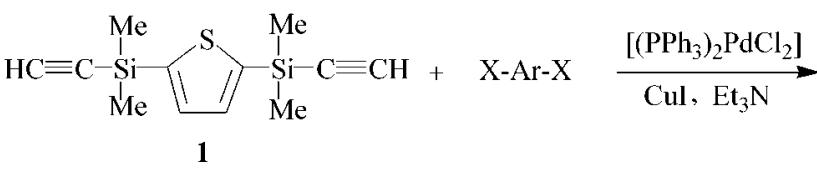

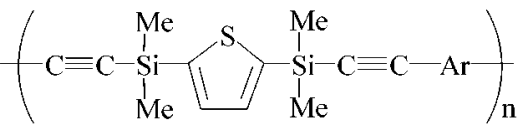

$$
\begin{aligned}
& \text { 2- } 7
\end{aligned}
$$

\footnotetext{
"Corresponding author. F-mail: ywkwak'oibh.knu.ac.kT
}

catalytic amount of bis(triphenylphosphinc)palladium(II) chloride and copper(I) iodide in refluxing triethy lamine.

\section{Experimental Section}

General Procedures. All reactions were carricd out under an atmosphere of dry nitrogen. Trietlyylamine used as the solvent for polymerization was dricd over $\mathrm{KOH}$ and distilled prior to use. The aromatic dihalides and the Pd catalyst used were purchased from Aldrich Chemical Company and used without further purification. GC analyses were performed using a Hewlett-Packard 5890 instrument on a HP-1 capillary column (cross-linked 5\% metly lphenylsiliconc. 25 m). ${ }^{1} \mathrm{H},{ }^{13} \mathrm{C}$ and ${ }^{29} \mathrm{Si}$ NMR spectra were run on a Bruker Avance 400 spectrometer. Mass spectra were obtained by a Shimadzu model QP-1000A spectromeler. UV/sisible and IR spectra were recorded on Shimadzu UV-2100 PC and Mattson Galaxy 7020A FT-IR spectromeiers. Molecular weights of oligomers were delermined by gel permeation chromalograply (GPC) relative to polystyrenc standards. using Shodex $80+$ and 80.3 as the column and using THF as the eluent. Thermogravimetric analyses were performed on a Rhometric STA 1500 thermal analyer. The temperature program for the thennogravimetric analysis was from room temperature to $1200^{\circ} \mathrm{C}$ with a typical heating rate of $10^{\circ} \mathrm{C} /$ min under argon flow rate of $40 \mathrm{~mL} / \mathrm{min}$. The thermolysis of the oligomer 3 were carried out in an alumina boat which was placed into an alumina tube $(1 \mathrm{~m}$. i.d. $3 \mathrm{~cm})$ under an atmosplece of flowing argon (50 $\mathrm{mL} / \mathrm{min})$. using a temperature program of $10^{\circ} \mathrm{C} / \mathrm{min}$ for $1 \mathrm{~h}$ at the thermolysis temperature. Elemental analyses were perfomed by a FISONS. EA 1106 elemental analyer.

Preparation of 2,5-Bis(ethynyldimethylsilyl)thiophene (1). In a three neck flask equipped with a condenser, dropping funnel and magnetic bar were placed $8.4 \mathrm{~g}(0.10$ 
mol) of thiophene and $29.1 \mathrm{~g}(0.25 \mathrm{~mol})$ of N.N.N'.N'tetramethy lethylenediamine (TMEDA) in $250 \mathrm{~mL}$ of anlydrous hexane at room temperature. A solution of butyllithium in hexanes ( 1.6 M. $156 \mathrm{~mL} .0 .25 \mathrm{~mol}$ ) was placed in the dropping funnel and slowly added dropwise to the well stirred solution under nitrogen at room temperature. ${ }^{l 1}$ After being stirred for an additional $5 \mathrm{~h}$ at room temperature, a solution of $23.7 \mathrm{~g}(0.25 \mathrm{~mol})$ of clulorodimethylsilane in 5.5 $\mathrm{mL}$ of anhydrous hexane was added dropwise to the reaction mixture maintained at $-78^{\circ} \mathrm{C}$. After addition was completed. the reaction mixture was stirred for $12 \mathrm{~h}$ at room temperature followed by filtration of the salts, then the organic layer was treated with water and dried over anhydrous magnesium sulfate. The volatile solvent was evaporated and the residue was distilled under reduced pressure to give $12.6 \mathrm{~g}(63.0$ munol, $63 \%$ ) of 2.5 -bis(dimethylsilyl)thiophene. The spectral properties of 2.5-bis(dimetly lsilyl)thiophene are in agreement with those previously reported. " For the preparation of 2.5-bis(chlorodimethylsilyl)thiophene, in a $100 \mathrm{~mL}$ two neck flask fitted with a reflux condenser and a rubber septum was placed a mixture of $3.6 \mathrm{~g}$ (18.0 mmol) of 2.5bis(dimetlylsilyl)thiophene and about $6 \mathrm{mg}$ of palladium dicluloride in $70 \mathrm{~mL}$ of carbontetracluloride. The mixture was heated to reflux for $3 \mathrm{~h}$. After evaporation of the solvent. the residue was distilled under reduced pressure to afford $4.3 \mathrm{~g}$ (16 mmol. $89 \%$ ) of 2.5-bis(clulorodimethylsilyl)thiophene. The spectral data of this product are identical with the previously reported values. "la,l?

For the preparation of 2.5-bis(ethym ldimethylsilyl)thiophene 1, a solution of $4.5 \mathrm{~g}(17 \mathrm{mmol})$ of 2.5-bis(chlorodimethylsily l)thiophene in $10 \mathrm{~mL}$ THF was added dropwise to a solution of ethy ny lmagnesium bromide in THF $(0.5 \mathrm{M}$. $90 \mathrm{~mL}$. $45 \mathrm{~mm}$ ) . After the addition was finished, the mixture was stirred for $12 \mathrm{~h}$ at $30^{\circ} \mathrm{C}$ followed by the filtration of the salts. The organic layer was treated with water and dried over anhydrous magnesium sulfate. The volatile solvent was exaporated and the residue was fractionally distilled under reduced pressure to give $2.9 \mathrm{~g}$ (11.7 mmol. $69 \%$ ) of 1. Compound 1: b.p. $104{ }^{\circ} \mathrm{C}$ ( 10 torr). $\mathrm{IR}: v(\mathrm{HC} \equiv) 3279 . v(\mathrm{C}-\mathrm{H}) 2963 .(\mathrm{C} \equiv \mathrm{C}) 2037 \mathrm{~cm}^{-1} . \mathrm{UV}$ : $\lambda_{\text {max }}\left(\mathrm{CHCl}_{3}\right) 243 \mathrm{~mm}(\varepsilon=13900)$. ${ }^{1} \mathrm{H}$ NMR $\left(\mathrm{CDCl}_{3}\right): \delta 0.56$ (s. $12 \mathrm{H}, \mathrm{SiCH}_{3}$ ). 2.55 (s. $2 \mathrm{H} . \mathrm{C} \equiv \mathrm{CH}$ ). 7.53 (s. $2 \mathrm{H}$, thiophene). ${ }^{1 .} \mathrm{C} \mathrm{NMR}\left(\mathrm{CDCl}_{3}\right): \delta 0.42 .86 .74,96.09,136.86,1+2.43 .{ }^{-9} \mathrm{Si}$ NMR $\left(\mathrm{CDCl}_{3}\right): \delta-26.73$. MS $m z$ (rel. intensity): $248\left(\mathrm{M}^{\prime}\right.$. 19). $233(100) .218$ (1). 183 (1). 165 (2). 145 (1). 143 (2). 109 (11).93 (12). 83 (39). 77 (5). $75(8) .73(7) .67(13) .55$ (28) $53(50)$. Anal. calcd for $\mathrm{C}_{1} \mathrm{H}_{16} \mathrm{SSi}_{2}$ : C. $58.00 ; \mathrm{H} .6 .49$. Found: C. $57.85:$ H. 6.58

Polymerization of 1 with 1,4-Dibromobenzene. A mixture of $0.25 \mathrm{~g}(1.0 \mathrm{mmol})$ of $1.0 .24 \mathrm{~g}(1.0 \mathrm{mmol})$ of 1.4 -dibromobenzene. $2.0 \mathrm{mg}\left(2.8 \times 10^{-3} \mathrm{mmol}\right)$ of bis(triphemy lphosphine)palladium(ll) chloride. $8.6 \mathrm{mg}\left(+.5 \times 10^{-2} \mathrm{mmol}\right)$ of cuprous iodide and $20 \mathrm{mg}\left(7.6 \times 10^{-2} \mathrm{mmol}\right)$ of triphenylphosphine in $12 \mathrm{~mL}$ of triethy lamine was stirred at $89^{\circ} \mathrm{C}$ for $16 \mathrm{~h}$. The reaction mixture was filtered. and after evaporation of the solvent, the residue was taken up in THF. Addition of pentane to the solution precipitated the oligomer.
The oligomer was purified with repeated precipitation from THF by addition of pentane and dried under reduced pressure to give $0.15 \mathrm{~g}$ of poly $\{[2.5$-bis(etly ny lenedimetly $1-$ sily lene)thienylene](1.4-phenylene)\} (2) ( $46 \%$ yield. light brown solid). The oligomer is soluble in common organic solvents such as THF, cluloroform and toluene. Compound 2: $\mathrm{Aw}=7400 . \mathrm{An}=4200(\mathrm{M} / \mathrm{w} / \mathrm{hl}=\mathrm{l} .76) . \mathrm{IR}: v(\mathrm{C} \equiv \mathrm{C}) 2160$ $\mathrm{cm}^{-1}$. UV: $\lambda_{\text {oll }}\left(\mathrm{CHCl}_{3}\right) 28+\mathrm{lm}(33000) .298 \mathrm{lml}(31500)$. ${ }^{l} \mathrm{H}$ NMR $\left(\mathrm{CDCl}_{3}\right): \delta 0.61$ (s. $\left.12 \mathrm{H} . \mathrm{SiCH}_{3}\right), 7.48$ (s, $4 \mathrm{H}$. phenylene ring protons), 7.56 (s, $2 \mathrm{H}$, thienylene ring protons). ${ }^{1.3} \mathrm{C} \mathrm{NMR}\left(\mathrm{CDCl}_{3}\right): \delta 0.47,94.10,106.24 .123 .27$, 132.06. 136.75, 143.09. ${ }^{29} \mathrm{Si} N \mathrm{NMR}\left(\mathrm{CDCl}_{3}\right):-26.46$. Anal. calcd. For $\left(\mathrm{C}_{1 \times \mathrm{H}_{1 \times} \mathrm{SSi}}\right) \mathrm{n}$ : C. 67.02: H. 5.62. Found: C. 64.94: H. 5.34 .

Polymerization of 1 with $4,4^{\prime}$-Dibromobiphenyl. A mixture of $0.27 \mathrm{~g}(1.1 \mathrm{mmol})$ of $1.0 .31 \mathrm{~g}(1.0 \mathrm{mmol})$ of $4.4^{\prime}-$ dibromobipheny $1,1+\mathrm{mg}\left(2.0 \times 10^{-2} \mathrm{mmnol}\right)$ of bis(tripheny $\mathrm{l}-$ phosphine)palladium(II) chloride and $5.7 \mathrm{mg}\left(3.0 \times 10^{-2}\right.$ mmol) of cuprous iodide in $12 \mathrm{~mL}$ of trietlylamine was stirred at $89^{\circ} \mathrm{C}$ for $16 \mathrm{~h}$. On completion of the reaction. 0.35 $\mathrm{g}$ of poly $\{[2.5$-bis-(ethy my lenedimethy lsily lene)thienylene] (4.4'-bipheny lene) $\}$ (3) was isolated in a similar manner as described in the preceding experiment $(83 \%$. brown solid). Compound 3: $\mathrm{h} w=3000 . \mathrm{h} / \mathrm{l}=2100(\mathrm{M} / \mathrm{w} / \mathrm{h}=1.43)$. IR: $v(\mathrm{C} \equiv \mathrm{C}) 2158 \mathrm{~cm}^{-1}$. UV: $\lambda_{\text {man }}\left(\mathrm{CHCl}_{3}\right) 300 \mathrm{~nm}(\varepsilon=29500)$. ${ }^{\prime} \mathrm{H}$ NMR $\left(\mathrm{CDCl}_{3}\right): \delta 0.59$ (s, 12H. $\left.\mathrm{SiCH}_{3}\right) .7 .44-7.60(\mathrm{~m}$. $10 \mathrm{H}$, thienylene and biphenylene ring protons). ${ }^{13} \mathrm{C} \mathrm{NMR}$ $\left(\mathrm{CDCl}_{3}\right): \dot{\delta} 0.49,92.67 .106 .58 .126 .89 \% 128.69,132.73$. 136.64. 140.56, 143.26. ${ }^{2}$ Si NMR $\left(\mathrm{CDCl}_{3}\right): \delta-26.46$. Anal. calcd. for $\left(\mathrm{C}_{2 \cdot 1} \mathrm{H}_{2} \mathrm{SS}_{2}\right)$ n: C, $72.30 ; \mathrm{H}, 5.56$. Found: C.69.28: H. 5.40 .

Polymerization of 1 with 9,10-Dibromoanthracene. A mixture of $0.27 \mathrm{~g}(1.1 \mathrm{mmol})$ of $1.0 .34 \mathrm{~g}(1 \mathrm{mmol})$ of 9.10 dibromoanthracene, $14 \mathrm{mg}\left(2.0 \times 10^{-2} \mathrm{mmol}\right)$ of bis(triphenylphosphine)palladium(II) chloride and $5.7 \mathrm{mg}\left(3.0 \times 10^{-2}\right.$ mmol) of cuprous iodide in $12 \mathrm{~mL}$ of triethylamine was stirred at $89^{\circ} \mathrm{C}$ for $16 \mathrm{~h}$. On completion of the reaction. 0.35 $\mathrm{g}$ of poly $\{$ [2.5-bis(ethy ny lenedimethylsily lene)thiemylene] (9.10-anthrylene) \} (4) was isolated in a similar manuer (78\% yield, brick red solid). Compound $4: 1 / \mathrm{w}=3000 . \mathrm{A} / \mathrm{n}$ $=2100(1 / \mathrm{w} / \mathrm{A} / \mathrm{n}=1.43) . \mathrm{IR}: v^{\prime}(\mathrm{C} \equiv \mathrm{C}) 2131 \mathrm{~cm}^{-1}$. UV: $\lambda_{\mathrm{mll}}$ $\left(\mathrm{CHCl}_{3}\right) 274 \mathrm{lml}(\varepsilon=35200) .400 \mathrm{~nm}(\varepsilon=10200) .418 \mathrm{~lm}$ $(\varepsilon=21100) .443 \mathrm{~nm}(\varepsilon=25600)$. 'H NMR $\left(\mathrm{CDCl}_{i}\right): \delta 0.78$ (s. $\left.12 \mathrm{H}, \mathrm{SiCH}_{3}\right) .7 .40-7.80(\mathrm{~m} .6 \mathrm{H}$, thienylene and anthrylene protons). $8.43-8.75$ (m. $4 \mathrm{H}$. anthrylene protons). ${ }^{1 .} \mathrm{C}$ NMR $\left(\mathrm{CDCl}_{3}\right): \delta(0.80,103.39 .105 .56,127.18 .127 .53$. 128.36. 132.51. 136.85. 143.44. ${ }^{29} \mathrm{Si}$ NMR $\left(\mathrm{CDCl}_{i}\right): \delta$ -26.17. Anal. calcd for $\left(\mathrm{C}_{26} \mathrm{H}_{2} \mathrm{SSS}_{2}\right)$ n: C. 73.88: H. 5.25 . Found: C. 71.15 : H. 5.32 .

Polymerization of 1 with 2,5-Dibromopyridine. A mixture of $0.27 \mathrm{~g}(1.1 \mathrm{mmol})$ of $1.0 .24 \mathrm{~g}$ (1.0 mmol) of 2.5 dibromopyridine. $1+\mathrm{mg}\left(2.0 \times 10^{-2} \mathrm{mmol}\right)$ of bis(triphenylphosphine)palladium(II) chloride and $5.7 \mathrm{mg}\left(3.0 \times 10^{-2}\right.$ mmol) of cuprous iodide in $12 \mathrm{~mL}$ of triethylamine was stirred at $89^{\circ} \mathrm{C}$ for $16 \mathrm{~h}$. On completion of the reaction. 0.18 $\mathrm{g}$ of poly $\{$ [2.5-bis(ethy mylenedimethylsilylene)thiemylene] (2.5-pyridylene)? (5) was isolated in a similar mamer $(52 \%$ 
yield. dark brown solid). Compound 5 : $M \mathrm{fw}=2200 . \mathrm{h} / \mathrm{n}=$ $800(\mathrm{hw} / \mathrm{h} / \mathrm{n}=2.75) . \mathrm{IR}: v(\mathrm{C} \equiv \mathrm{C}) 2162 \mathrm{~cm}^{-1}$. UV: $\lambda_{\text {пган }}$ $\left(\mathrm{CHCl}_{3}\right) 305$ nuा $(\varepsilon=17200)$. ${ }^{\mathrm{H}} \mathrm{H}$ NMR $\left(\mathrm{CDCl}_{3}\right): \delta 0.57$ (br. s. $12 \mathrm{H}$. $\mathrm{SiCH}_{3}$ ) $7.36-7.55$ (m. 3H. py ridylene and thienylene protons). 7.60-7.79 (m. lH. pyridylene proton). 8.66 (s. lH. py ridylene proton). ${ }^{13} \mathrm{C} \mathrm{NMR}\left(\mathrm{CDCl}_{3}\right): \delta-0.01,0.10 .94 .60$. $97.86,102.66,104.62,119.47,126.79,126.87,136.69$, 136.74. 136.83. 136.87, 138.95, 139.00. 1+1.62, 142.25. 142.30. 142.48. 142.52. 152.75. ${ }^{2} \mathrm{Si}$ NMR $\left(\mathrm{CDCl}_{3}\right): \delta$ -25.96. -26.08. Anal. calcd. for $\left(\mathrm{C}_{1}=\mathrm{H}_{1}=\mathrm{NSSi}_{2}\right)_{\mathrm{ll}}: \mathrm{C}, 63.10$ : H. 5.30; N. 4.33. Found: C. 61.57: H. 5.17: N. 3.85 .

Polymerization of 1 with 2,5-Dibromothiophene. A mixture of $0.27 \mathrm{~g}(1.1 \mathrm{mmol})$ of $1.0 .2+\mathrm{g}$ (1 mmol) of $2.5-$ dibromothiophene. $1+\mathrm{mg}\left(2.0 \times 10^{-2}\right.$ numol) of bis(tripheny $1-$ phosphine)palladium(II) clloride and $5.7 \mathrm{mg}\left(3.0 \times 10^{-2}\right.$ mnol) of cuprous iodide in $12 \mathrm{~mL}$ of trietly lamine was stirred at $89{ }^{\circ} \mathrm{C}$ for $16 \mathrm{~h}$. On completion of the reaction. 0.23 $\mathrm{g}$ of poly \{ $[2.5$-bis(ethyny lenedimethylsily lene)thieny lene] (2.5-thienylene) $\}$ (6) was isolated in the same manner $(66 \%$ yield. dark brown solid). Compound $6: \mathrm{k} w=5000 \mathrm{~h} / \mathrm{hl}=$ $1300(\mathrm{~h} / \mathrm{w} / \mathrm{h}=3.85)$. IR: $v(\mathrm{C} \equiv \mathrm{C}) 21+9 \mathrm{~cm}^{-1}$. UV: $\lambda_{\text {เпах }}$ $\left(\mathrm{CHCl}_{3}\right) 25+\mathrm{nm}(\varepsilon=10600) .320 \mathrm{~nm}(\varepsilon=13100) .335 \mathrm{~nm}$ $(\varepsilon=13300)$. 'H NMR $\left(\mathrm{CDCl}_{3}\right): \delta 0.55$ (s. $\left.12 \mathrm{H} . \mathrm{SiCH}_{3}\right) .7 .09$ (s. $2 \mathrm{H}$. thienylene protons). 7.49 (s. $2 \mathrm{H}$, thieny lene protons). ${ }^{1.3} \mathrm{C}$ NMR $\left(\mathrm{CDCl}_{3}\right): \delta 0.32 .97 .66 .98 .60,12+.66 .130 .03$. 136.86. 142.78. ${ }^{-9} \mathrm{Si} \mathrm{NMR}\left(\mathrm{CDCl}_{3}\right): \delta-26.21$. Anal. calcd. for $\left(\mathrm{C}_{16} \mathrm{H}_{16} \mathrm{~S}_{2} \mathrm{Si}_{2}\right)_{11}:$ C. 58.48: H. 4.91. Found: C. 56.80: H. 4.85 .

Polymerization of 1 with 2,6-Diiodo-4-nitroaniline. A mixture of $0.27 \mathrm{~g}(1.1 \mathrm{mmol})$ of $0.39 \mathrm{~g}(1.0 \mathrm{mmol})$ of $2.6-$ diiodo-t-nitroaniline. $1+\mathrm{mg}\left(2.0 \times 10^{-2} \mathrm{mmol}\right)$ of bis(triphemy phosphine)palladium(II) clloride and $5.7 \mathrm{mg}\left(3.0 \times 10^{-2}\right.$ mmol) of cuprous iodide in $12 \mathrm{~mL}$ of triethy lamine was stirred at $89{ }^{\circ} \mathrm{C}$ for $16 \mathrm{~h}$. On completion of the reaction. $0.3 \mathrm{l}$ g of poly \{ $[2.5$-bis(ethy ny lenedimethylsily lene)thieny lene] [2.6-(4-nitroanilylene)]\} (7) was isolated in the same manner (77\% y ield. brick red solid). Compound $7: \mathrm{Aw}=2200 \mathrm{M} / \mathrm{n}=$ $1100(\mathrm{~A} / \mathrm{w} / \mathrm{M} / \mathrm{n}=2.0) . \mathrm{IR}: \quad v(\mathrm{C} \equiv \mathrm{C}) 21+7 \mathrm{~cm}^{-1} . \mathrm{UV}: \lambda_{\text {rata }}$ $\left(\mathrm{CHCl}_{3}\right) 28+\mathrm{nm}(\varepsilon=19500) 36+\mathrm{nm}(\varepsilon=12100) .{ }^{\prime} \mathrm{H}$ NMR $\left(\mathrm{CDCl}_{3}\right): \delta 0.59$ (s. $\left.12 \mathrm{H}, \mathrm{SiCH}_{3}\right) .5 .5+$ (s. $2 \mathrm{H} . \mathrm{NH}_{2}$ ), 7.50 (s. $2 \mathrm{H}$. thieny lene protons). 8.19 (s. $2 \mathrm{H}$. phenylene protons). ${ }^{13} \mathrm{C}$ NMR $\left(\mathrm{CDCl}_{3}\right): \delta 0.29,100.28,103.46,106.47,129.05$. 136.90. 137.62. 142.60. 154.28. ${ }^{-9} \mathrm{Si} \mathrm{NMR}\left(\mathrm{CDCl}_{3}\right): \delta$ -25.72. Anal. calcd. for $\left(\mathrm{C}_{1 \times} \mathrm{H}_{18} \mathrm{~N}_{2} \mathrm{O}_{2} \mathrm{SSi}_{2}\right)_{11}:$ C. $56.5 \mathrm{l}: \mathrm{H}$, 4.74: N. 7.32. Found: C. 55.31: H. 4.36: N. 6.94.

\section{Results and Discussion}

In 1975. Sonogashira. ${ }^{3}$ Cassar. ${ }^{-1}$ Heck et al. ${ }^{5}$ reported independently that monosubstituted acetrlenes are easily converted into disubstituted acetylenes by the palladium(II)catalyzed reaction with aryl halides in a basic amine. Linear polymers of alternating ethynylene and arylene units were sy nthesized by a cross-coupling reaction utilizing the same catalyst." Corrin ef $a .^{12}$ reported that the preparation of dipheny lsily lene polymers containing diethyny lenearylene unit in the presence of a $\mathrm{Pd}(\mathrm{II})$-CuI catalyst. West ${ }^{1.3}$ and
Ishikawa et $a l^{1+}$ reported that alternating organosilicon copolymers consisting of disilanylene and etlyny lene units are prepared by the different methods. The preparation of disilany lene polymers containing etly ny lenepheny lene unit in the polymer backbone was reported by West. ${ }^{15}$ The first synthesis of polymer bearing disilanylene and ethynlenepyridylene units in the conjugated backbone has been reported by lshikawa and Kunai. ${ }^{16}$ Recently organosilicon poly mers with silole (=silacyclopentadiene) skeleton have been extensively studied as the new $\pi$-electron system with unusual optical properties. ${ }^{\text {| } a .1 \text {. }}$ ?

We are concerned with the synthesis and properties of organosilicon oligomers consisting of a 2.5-bis(ethynylenedimethy lsilylene)thieny lene unit and an arylene unit as the $\pi$-electron system in the oligomer backbone. The oligomers were prepared from the reaction of 2.5-bis(etly ny ldimetlyysilyl)thiophene (1) and (hetero)aromatic dilalides in a refluxing triethylanine solution in the presence of a mixture of catalysts composed of bis(triphenylphosphine)palladium (II) chloride and copper(l) iodide. The reaction was completed after about $16 \mathrm{~h}$ which was monitored by the disappearance of acetylenic bands in the IR spectrum of 1 at $2037 \mathrm{~cm}^{-1}$.

A mixture of 1 equivalent of $\mathbf{1}$ and 1,4 -dibromobenzene in the presence of a $\left(\mathrm{PPh}_{3}\right)_{2} \mathrm{PdCl}_{2}-\mathrm{Cul}$ catalyst was heated in triethylamine. Poly \{ $\mid 2.5$-bis(ethy ny lenedimethylsily lene)thienylene](1.4-pheny lene) $\}$ (2) with a molecular weight of 7400 was produced after several reprecipitation in pentane. Simular reactions of $\mathbf{1}$ with (hetero)aromatic dihalides under the same conditions gave products corresponding to poly \{[2.5-bis(ethyn lenedimethy lsilylene)thientene](arylene)\} (3-7) with molecular weights of $2200-5000$ in moderate yields. Oligomers 2-7 are brown or brick-red coloured solids and are soluble in common organic solvents such as tetrahydrofuran, chloroform and toluene. The structures of oligomers 2-7 were identified by spectroscopic methods. The streching frequency of carbon-carbon triple bond in IR spectra of oligomers 2-7 appears as a strong peak between at 2131 and $2162 \mathrm{~cm}^{-1}$. The $\mathrm{C} \equiv \mathrm{C}$ bond stretching absorption of the anthracene containing oligomer 4 occurs at $2131 \mathrm{~cm}^{-1}$ as Corriu has observed in the case of the polymer containing tetrapheny lsilole ${ }^{12 a}$ or diphenylsilylene ${ }^{12 h}$ in the backbone. This is probably due to some degree of conjugation between the arylene and ethynylene unit for 4 . The oligomers 2-7 exhibit strong UV absorption band at $25+-1+3 \mathrm{rm}$ in chloroform solution. which are lower in energy than the monomer 1. ${ }^{18}$ The UV absorption bands and the extinction coefficients per $\{[2,5$-bis(ethyn lenedimethy lsilylene)thieny]ene (arylene)\} $\}$ unit of oligomers 2-7 are given in Table 1.

The ${ }^{1} \mathrm{H}$ NMR spectra of oligomers 2-7 obtained show one signal due to dimethylsilyl group at $\delta 0.61,0.59,0.78 .0 .57$. 0.55 . and $0.59 \mathrm{ppm}$. respectively: The signals for the aromatic protons in the oligomer 2 are both singlet. due to phenylene and thienylene unit at $\delta 7.48$ and $7.56 \mathrm{ppm}$. respectively: The ${ }^{1 .} \mathrm{C}$ NMR signals for both the ethy nylene carbons. $C_{t i}$ and $C_{\beta}$ of the oligomers are more deshielded relative to those for the monomer 1 . The signal for the $C_{\alpha}$ of 
Table 1. Properties of Monomer 1 and Oligomers 2-7

\begin{tabular}{|c|c|c|c|c|c|c|c|c|c|}
\hline \multirow{3}{*}{ Compound } & \multirow{3}{*}{$-\mathrm{Ar}-$} & \multirow{3}{*}{$\begin{array}{c}\mathrm{IR} \\
v(\mathrm{C} \equiv \mathrm{C}) \\
\left(\mathrm{cm}^{-1}\right)\end{array}$} & \multirow{3}{*}{$\begin{array}{c}\text { UV } \\
\text { dmax. nm } \\
\text { (E/repeated unit) }\end{array}$} & \multicolumn{4}{|c|}{ VMR (ppm) } & \multirow{3}{*}{$W w(W / 1 / n)$} & \multirow{3}{*}{ Color } \\
\hline & & & & \multicolumn{2}{|c|}{${ }^{1.3} \mathrm{C}^{92}$} & 'H & ${ }^{21} \mathrm{Si}$ & & \\
\hline & & & & $\mathrm{C}_{\text {(s) }}$ & $\mathrm{C}_{\beta}$ & SiMe & & & \\
\hline 1 & & 2037 & $243(13900)$ & 87.64 & 96.09 & 0.56 & -26.73 & & \\
\hline 2 & & 2160 & $\begin{array}{l}284(33000) \\
298(31500)\end{array}$ & 94.10 & 106.24 & 0.61 & -26.46 & $7400(1.76)$ & light brown \\
\hline 3 & & 2158 & $300(29500)$ & 92.67 & 106.58 & 0.59 & -26.46 & $3000(1.43)$ & brown \\
\hline 4 & & 2131 & $\begin{array}{l}274(35200) \\
400(10200) \\
418(21100) \\
4+3(25600)\end{array}$ & 103.39 & 105.56 & 0.78 & -26.17 & $3000(1.43)$ & brick red \\
\hline 5 & & 2162 & $305(17200)$ & $\begin{array}{l}94.60 \\
97.86\end{array}$ & $\begin{array}{l}102.66 \\
104.62\end{array}$ & 0.57 & $\begin{array}{l}-25.96 \\
-26.08\end{array}$ & $2200(2.75)$ & dark brown \\
\hline 6 & & 2149 & $\begin{array}{l}254(10600) \\
320(13100) \\
335(13000)\end{array}$ & 97.66 & 98.60 & 0.55 & $-26,21$ & $5000(3.85)$ & dark brown \\
\hline 7 & & 2147 & $\begin{array}{l}284(19500) \\
364(12100)\end{array}$ & 100.28 & 103.46 & 0.59 & -25.72 & $2200(2.00)$ & brick red \\
\hline
\end{tabular}

"Si-C $C_{p} \equiv C_{p}$ Ar. "plyysical state: solid.

ethynylene unit of the oligomer $\mathbf{4}$ appears larther downlield with respect to those for the other oligomers, because there may be some electron delocalization in $4 .^{12 \mathrm{tat}}$ In the particulat case of oligomer 5 containing 2,5-pyridylene unit, two $\mathrm{C}_{\alpha}(\delta$ 94.60 and $97.86 \mathrm{ppm}$ ) and 1 wo $\mathrm{C}_{\beta j}(\delta 102.66$ and 104.62 ppm) are observed, duc to each ethynyl-pryidine linkage being in either the 2- or 5-pyridine position. Previously Corriu and co-workers also observed the multiple resonanees for ethynylene carbons of the 2.5-pyridylene polymers containing a tetraphenylsilole ${ }^{124}$ or diphenylsilylene unit. ${ }^{12 \mathrm{~d}}$

Recently, Ishikawa et al. ${ }^{\text {to }}$ have clearly interpteded the multiple resonances for the ethynylene carbons in the ${ }^{13} \mathrm{C}$ NMR spectra of polyl(2,5-dicthynylenepyridylene)disilanylenel from the examination of ${ }^{13} \mathrm{C}$ NMR spectra of 1,2-bis(2-

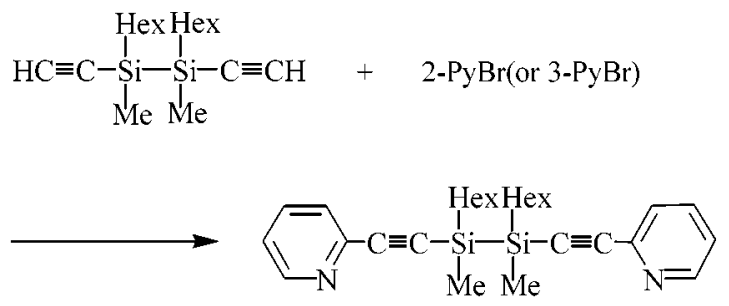

A<smiles>C[Si]([K])([Hg])[Si](C)(C#Cc1cccnc1)[Si](C)(C)C#Cc1cccnc1</smiles>

pyridylethynyl)- and 1,2-bis(3-pyridylethynyl)-1,2-dihexyl1,2-dimethyldisilane (A and $\mathbf{B}$ ) as model compounds.

The ${ }^{27}$ Si NMR spectrum of the monomer 1 shows a single resonanee at $\delta-26.73 \mathrm{ppm}$ and those of the oligomers (2-4, 6-7) reveal also a single resonance and that of oligomer 5 reveals two resonances at -25.96 and $-26.08 \mathrm{ppm}$. These results suggest that the oligomers have the regular alternating structure of 2,5-bis(ethynylenedimethylsilylene)thienylene and arylene units.

The thermal behavior of oligomers 2-7 was examined by thermogravimetric analysis (TG $\Lambda$ ) in argon almosphere. $\mathrm{TG} A$ analyses were run from $25{ }^{\circ} \mathrm{C} \quad 10 \quad 1200{ }^{\circ} \mathrm{C}$. The oligomers were stable until about $220^{\circ} \mathrm{C}$ without any weight loss and took place decomposition at higher temperature. I1 was shown that the oligomers was decomposed in two steps. The lirst step in case of oligomer 3 was rapid weight loss at about $250-500{ }^{\circ} \mathrm{C}$ and the second was continuous weight loss starting at $700^{\circ} \mathrm{C}$. The weight remaining at $1200^{\circ} \mathrm{C}$ was found to be $22 \%, 57 \%, 55 \%, 28 \%, 42 \%$, and about $20 \%$ of the initial weight for $2-7$, respectively. The cross-linking process $^{19}$ during the thermolysis of 3 , a selection of the oligomers, was monitored by the changes in the IR spectra at diflerent temperatures $\left(200,300\right.$, and $\left.400^{\circ} \mathrm{C}\right)$. When the sample is heated above $200^{\circ} \mathrm{C}$. the characteristic absorption band of acelylene group at $2158 \mathrm{~cm}^{-1}$ has disappeared and one new absorption peak corresponding to the carboncarbon double bond appeared at $1602 \mathrm{~cm}^{-1}$. The combustion analysis for the oligomers 2-7 shows lower carbon content than theoretical values. ${ }^{9}$. 22.16 .20 This would be due to the formation of carbon containing ceramics, such as $\beta$-SiC 
during the analysis. In fact. the IR spectrum of the ash obtained from combustion of oligomer 3 at $1000^{\circ} \mathrm{C}$. the same temperature as used for elemental analysis. shows a strong absorption at $1089 \mathrm{~cm}^{-1}$ due to $v_{s j-k}$, with a weak shoulder around $1200 \mathrm{~cm}^{-1}$ due to $v_{\mathrm{s}-\mathrm{s}}$ as Kunai have observed in the case of the organosilicon polymers with a dietly ny lantluacene unit in the backbone.

In conclusion. we have prepared oligomers 2-7 with molecular weights of 2200-7400 having a 2.5-bis(ethynylenedimethylsilylene)thienylene system linked by an arylene in the backbone. by dehydrohalogenation of 2.5-bis(ethynydimethylsilyl)thiophene (1) and (hetero)aromatic dihalides in the presence of a $\left(\mathrm{PPh}_{3}\right)_{2} \mathrm{PdCl}_{z}-\mathrm{CuI}$ catalyst. Thermal behaviors of oligomers were also examined.

Acknow ledgement. This work was supported by Korea Research Foundation Grant (KRF-99-015-Dl0061).

\section{References}

1. Corriu. R. J. 1.: Devylder. N.: Guérin. C.: Henner. B.: Jean. A. Oryamomotallics 1994. 13.3194. and relerences cited therein.

2. Ishikawa. M.: Ohshita. J. Silicon and Germanium Containing

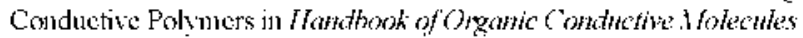
and Folymers: Nalwa, II. S., F.d: Wiley: New York, 1997: Vol. 2. Chapter 15 , and references eited therein

3. Sonogaslira, K.: Tohda, Y.: Iagihara, N. Tetrahtedron lett. 1975. 467.

4. Cassar. L. J. Orgememet Chem. 1975.93.253.

5. Dieck. H. A.: Heck. F. R. J. Ongmomef Chem. 1975, 93. 259.

6. I Javens, S. I. Polym. Sor. Folmm. Ieth. Fd 1985. $23,587$.

7. (a) Trumbo, D. J .. Marvel, C. S. J. Folym. Sci. A Polvm. Chem. 1986, 2f, 2311. (b) Trumbo. D. I..: Mariel, C. S. J. Polym Sci .1 Folym. Chom. 1986. 24.2231. (c) Trumbo. D. L.: Murvel. C. S. $J$. Folm Scr. Al'ohm. Chom. 1987. 25.839.

8. Olishita. J: Kunai. A. Acta Lotym 1998. 49. 379 .

9. (a) Obshita. J.: Islii, M.: Ueno, Y: Yamashita, A.: Ishikawa, M. hacpomolecules 1994, 27, 558.3. (b) Ohshita. I: Yamasilita. A.: J liaoka. T.: Shimpo, A.: Kunai, A.: Islikawa, M. Hocronolecules 1997. 30. 1540. (c) Ohshita. J.: Shinpo. A.: Kunai. A. Macremotecules 1999. 38. 5998.

10. Chaduick. D. I.: Willbe. C. J. Chem. Soc., Pertin I 1977. 887.

11. (a) Olishita, J.: Kanaya, D.: Ishikawa, M. J. Organomet (hem. 1994, 468, 55. (b) IJu. S.S.: Wober. W. P. Folyme: Rullefin 1989,
21. 133. (c) Zhang. X. H.: West. R. J. Hohm. Sci. Polym. Chem. Ed. 1984. 22. 159 and 225 .

12. (a) Conitu. R. J. P’: Donglas. W. E.: Yang. Z. X. J. Organomet. (Them 1993, 456,35 . (b) Corriu, R. J. P.: Douglas. W. F.: Yante. 7.-X.: Gamier. F.: Yassar, A. J. Organomet. ('hem. 1991, 4I7, C50. (c) Corriu, R. I. P.; Douglas, W. F., Yang. 7.-X. J. Polym Sci. CPohm. Latt 1990. 28. 431. (d) Corriu. R. J. P'.: Domilas. W. E.: Yang. L. X.: Karakits. Y.: Cross. G. H.: Bloor. D. J. Oryomomet. Chem. 1993. 455.69.

13. Iwahara. T.: West. R.J. Chem. Soc. Chem. Commm 1988, 1079.

14. (a) Ishikawa, M.: I Lasegana, Y.: I Iatano. T.: Kunai. A.: Yamanaka, T. Organonetallics 1989, 8. 2741. (b) Ishikaua, M: Itorio, T.: Hatano. 1.: Kunai. A. Orgamomefallics 1993. 12. 2078.

15. Yuan. C.-H.: West. R. Appt. Orgemomef. Chem. 1994. \&, 423.

16. Kunai. A.: Tonoda. E.: Horata. K.: Ishikawa. M. Orgemometallics $1995,1+.714$

17. (a) Tamao. K.: Yamaguchi. S.: Shiozaki. M.: Nakagawa, Y.: Ito, Y. J. in (hem Soc 1992, 114, 5867. (b) Toroda, Г.: Kunai. A.: Ishikana. M. Organomefallics 1995. 14.1089. (c) Chen. W.: IjadiMaghsoodi. S.: Barton. T. J. Polym. I'repr 1997. 35. 189. (d) Ohshita. J.: Mimura. N.: Arase. H.: Nodona. M.: Kunai. A.: Komaguchi. K.: Shiotani. M.: Ishikawa. M. Macromolecules 1998, 31. 7985. (c) Sohn, H.: I Iuddleston. R. R.: Powell, D. R.: West. R.: Oka, K.: Yonghua, X. J. Alm. (hem. Soc 1999. 121, 2935. (1) Sanji. T.: Funaya. M.: Salurai. H. Chem. Leth 1999. 547. (g) Ohshita. J.: Hamaguchi. T.: Ionceda. E.: Kunai. A.: Komactuchi. K.: Shiotani. M.: Ishikawa. M.: Natia. A. Onganometallics 1999. 18. 1717. (h) Yamaguehi. S.: Goto, T.: Taman. K. Ingen: (Chem. Int. F.d 2000. 39, 1695. (i) Ohshita. I.: Nodono, M.: Takata, $\Lambda$. Kai, II.: Adachi. A.: Salatnaki, K.: Okita, K.: Kunai. A. Macromol. Chem. Ithes, 2000. 201.851.

18. (a) Shizuka. H.: Obuchi. H.: Ishikawa. M.: Kumada. M. $J$. Chem. Soc. Chem. Commun. 1981. 405. (b) Sakurai. H. J. Ongonomet. Chem. 1980, 200, 261. (c) Apeloig. Y. In The Chemistry of Organic Silicon Compounds: Patai. S..Rappoport. 7... T.ds.: Wilcy": Chichester. U.K.. 1989: Vol. 1. p 57.

19. (a) Kalo. J.: Nakamura. K.: Yamasaki. S.: Tokushige. K.: Amano. l. J. Potwm Sci af Polvm. Chem. 1989. 27. 1853. (b) IjadiMaghsoodi. S.: Pang. Y: Barton. T. J. J. Pohm Sci. .t Pohm. Chem 1990. 28. 955. (c) Corriu. R. J. P.: Gerbier. P.: Guérin. C.: IIenner, B. J. I.. Icant. A.: Mutin, P. H. Organometallics 1992, //, 2507. (d) Itoh. M.: Mitsuzaka, M: Inata, K.: Inouc. K. Hacromolecales 1994. 27. 7917. (e) P'ark. Y. T.: Seo. I. K.: Kim. Y.-R. Bull. Sortm Chem. Soc. 1996. 17. 480. (1) Ohshita. J.: Sumida. T:: Kunai. A.: Adachi. A.: Sakamaki. K.: Okita. K. Nacmonolecules 2000, 33.8890.

20. Manhart. S. A.: Adachi. A.: Sakamaki. K.: Okita. K.: Ohshita, I.: Oluno, T.: IJamaguchi. T: Kunai, A.: Kido, J. J. Organome't. Chem. 1999. 592. 52 . 